\title{
Pengaruh Perbedaan Kedalaman Tanam dan Volume Air terhadap Perkecambahan dan Pertumbuhan Benih Sorgum (Sorghum Bicolor (L.) Moench)
}

\section{Influence of Depth of Planting Difference and Water Volume Against Germination and Growth of Shorgum Seed (Sorghum Bicolor (L.) Moench)}

\author{
Febiasasti Trias Nugraheni ${ }^{1 *}$, Sri Haryanti ${ }^{2}$ Dan Erma Prihastanti ${ }^{2}$ \\ ${ }^{1}$ Mahasiswa Program Studi Biologi, Departemen Biologi, Fakultas Sains dan Matematika, Universitas \\ Diponegoro \\ ${ }^{2}$ Departemen Biologi, Fakultas Sains dan Matematika, Universitas Diponegoro \\ Jl. Prof. Soedarto, SH, Tembalang, Semarang \\ *Email : feby.tnugraheni@yahoo.co.id
}

Diterima 24 September 2018 / Disetujui 6 November 2018

\begin{abstract}
ABSTRAK
Sorgum merupakan tanaman yang dapat digunakan sumber pangan dan dapat dijadikan alternatif pengganti gandum karena memiliki kandungan karbohidrat yang sama dengan gandum sebagai bahan baku tepung terigu. Produksi sorgum di Indonesia masih rendah, sehingga untuk mendapatkan bibit sorgum yang unggul dan berkualitas perlu memperhatikan kedalaman tanam dan volume air. Penelitian ini bertujuan untuk menganalisis pengaruh perbedaan kedalaman tanam dan volume air terhadap perkecambahan dan pertumbuhan sorgum (Sorghum bicolor (L.) Moench). Penelitian terdiri dari 2 unit, yaitu perkecambahan dan pertumbuhan sorgum yang menggunakan 9 perlakuan dengan 3 ulangan. Perlakuan kedalaman tanam terdiri dari $\mathrm{K} 1(1 \mathrm{~cm}), \mathrm{K} 2(3 \mathrm{~cm}), \mathrm{K} 3(5 \mathrm{~cm})$ dan volume air P1 $(150 \mathrm{ml}), \mathrm{P} 2(300 \mathrm{ml}), \mathrm{P} 3(600 \mathrm{ml})$. Kedua faktor dikombinasikan menjadi perlakuan K1P1, K1P2, K1P3, K2P1, K2P2, K2P3, K3P1, K3P2, K3P3. Penelitian ini menggunakan rancangan acak lengkap (RAL) faktorial. Faktorial. Data penelitian dianalisis dengan ANOVA yang dilanjutkan dengan uji lanjut Duncan pada taraf signifikasi 95\%. Hasil penelitian menunjukkan tidak ada pengaruh terhadap persentase perkecambahan, laju perkecambahan, tinggi tanaman, dan jumlah daun, tetapi terdapat perbedaan yang nyata terhadap berat basah, berat kering, dan panjang akar sorgum. Perlakuan K3P2 menunjukkan perkecambahan dan pertumbuhan sorgum terbaik.
\end{abstract}

Kata kunci : Sorgum, Sorghum bicolor (L.) Moench, kedalaman tanam, volume air

\begin{abstract}
Sorghum is a plant that can be used food sources and can be used as an alternative to wheat because it has the same carbohydrate content with wheat as raw material wheat flour. Production of sorghum in Indonesia is still low, so to get the seeds of superior and quality sorghum need to pay attention to the depth of planting and water volume. This study aims to analyze the effect of depth of planting and water volume on germination and growth of sorghum (Sorghum bicolor (L.) Moench). The study consisted of 2 units, namely germination and growth of sorghum using 9 treatments with 3 repetition. The treatment of plant depth consisted of K1 $(1 \mathrm{~cm}), \mathrm{K} 2(3 \mathrm{~cm}), \mathrm{K} 3(5 \mathrm{~cm})$ and water volume P1 $(150 \mathrm{ml}), \mathrm{P} 2(300 \mathrm{ml}), \mathrm{P} 3(600 \mathrm{ml})$. The two factors combined to treat K1P1, K1P2, K1P3, K2P1, K2P2, K2P3, K3P1, K3P2, K3P3. This study used a complete randomized design (RAL) factorial. The research data were analyzed by ANOVA followed by Duncan test at $95 \%$ significance level. The results showed no effect on the percentage of germination, germination rate, plant height, and number of leaves, but there were significant differences in wet weight, dry weight, and length of planting roots. The treatment of K3P2 showed the best germination and growth of sorghum.
\end{abstract}

Keywords : Sorghum, Sorghum bicolor (L.) Moench, depth of planting, water volume 


\section{PENDAHULUAN}

Indonesia merupakan negara yang kaya akan sumber bahan pangan namun banyak sumberdaya lokal yang belum dimanfaatkan hingga saat ini. Hal ini disebabkan karena ketahanan pangan yang terlalu bergantung pada satu komoditas, yaitu gandum. (Sirappa, 2003) sorgum merupakan komoditas pangan alternatif yang berpotensi cukup besar untuk dikembangkan di Indonesia karena tanaman ini memiliki daya adaptasi yang luas, toleran terhadap kekeringan, dapat berproduksi pada lahan marginal, relatif tahan terhadap hama dan penyakit (Sirappa, 2003). Tanaman sorgum dapat menjadi salah satu solusi dari permasalahan krisis pangan karena dapat dimanfaatkan untuk memenuhi kebutuhan pangan Indonesia untuk masa depan yang tidak hanya bergantung pada gandum saja Secara agronomis, sorgum mempunyai kelebihan, di antaranya toleransi terhadap kekeringan, kadar garam tinggi, dan daya adaptasi yang luas (Dajue and Guangwei, 2000).

Salah satu faktor yang mempengaruhi keberhasilan perkecambahan ialah faktor kedalaman tanam dan air. Semakin dalam kedalaman tanam maka benih yang ditanam akan semakin sulit tumbuh. Sebaliknya apabila benih ditanam pada kedalaman tanam yang dangkal, benih akan mudah tumbuh. Hal ini disebabkan oleh kadar oksigen yang terdapat di dalam tanah. Kadar oksigen akan semakin menurun dengan semakin dalam lapisan tanah (Ashari, 2006).

Perkecambahan dan pertumbuhan dari benih sorgum membutuhkan kedalaman tanam yang berbeda untuk tumbuh dengan baik. Kedalaman tanam yang dangkal menyebabkan benih akan lebih banyak mendapatkan cahaya yang akan digunakan untuk fotosintesis dan menghasilkan fotosintat lebih banyak, sedangkan benih yang ditanam lebih dalam akan mendapatkan cahaya matahari sedikit sehingga hasil fotosintatnya rendah dan pertumbuhannya lambat.

Air memiliki peran penting dalam perkecambahan dan pertumbuhan, apabila benih kekurangan air akan menghasilkan daya kecambah yang kurang serempak karena pembelahan sel terhambat, sedangkan dengan kondisi yang cukup akan menghasilkan perkecambahan terbaik. Menurut hasil penelitian Solichatun, dkk (2005) ketersediaan air akan mempengaruhi pertumbuhan dan perkembangan suatu tanaman. Penelitian lain dari data parameter pertumbuhan menunjukkan bahwa perlakuan perbedaan tingkat ketersediaan air (40, 60, 80, dan 100\% kapasitas lapang) mempengaruhi berat kering, laju pertumbuhan relatif, efisiensi penggunaan air, kadar saponin umbi, dan kadar saponin total tanaman ginseng jawa (Talinum paniculatum). Menurut penelitian Santoso dan Purwoko (2008), kedalaman tanam benih $1 \mathrm{~cm}, 2 \mathrm{~cm}, 3 \mathrm{~cm}$, dan $4 \mathrm{~cm}$ pada benih jarak pagar berpengaruh nyata hanya terhadap perkecambahan ketika benih ditanam pada kedalaman tanam $4 \mathrm{~cm}$ pada berbagai posisi tanam.

Perkecambahan benih mempunyai hubungan erat dengan viabilitas benih dan jumlah benih yang berkecambah dari sekumpulan benih yang merupakan indeks viabilitas benih. Parameter untuk viabilitas benih yang digunakan adalah persentase perkecambahan yang cepat dan pertumbuhan perkecambahan kuat. Hal ini mencerminkan kekuatan tumbuh yang dinyatakan sebagai laju perkecambahan (Sutopo, 2002). Viabilitas benih merupakan daya benih yang ditunjukkan oleh metabolismenya atau pertumbuhannya. Pola pertumbuhan sepanjang daur hidup pertumbuhan dicirikan melalui fungsi yang disebut kurva sigmoid yaitu kurva yang berbentuk S. Bentuk kurva sigmoid untuk semua tanaman kurang lebih tetap, tetapi penyimpangan dapat terjadi sebagai akibat variasi-variasi di dalam lingkungan (Tjitrosomo, 1999).

Berdasarkan latar belakang diatas maka perlu diadakan penelitian dengan judul "Pengaruh Perbedaan Kedalaman Tanam dan Volume Air Terhadap Perkecambahan dan Pertumbuhan Benih Sorgum (S. bicolor (L.) Moench).

\section{METODE PENELITIAN}

Penelitian dilaksanakan selama 1,5 bulan dimulai pada bulan Juni hingga Juli 2017. Lokasi penelitian adalah di desa Terban Kecamatan Jekulo Kabupaten Kudus. Alat yang digunakan 
dalam penelitian ini meliputi cangkul, gunting, cetok, penggaris, gelas ukur, ember, meteran, kamera digital, hand sprayer, gelas ukur, oven, timbangan digital, cutter.

Bahan yang digunakan dalam penelitian ini meliputi biji sorgum S. bicolor (L.) Moench varietas numbu dari toko pertanian di Semarang, polybag ukuran $35 \times 35 \mathrm{~cm}$, media tanah, air, pupuk kandang, sekam padi, alumunium foil, insektisida, decis, plastik, kertas, lidi, paranet $60 \%$, kertas label, spidol.

Persiapan Alat dan Bahan: Semua alat dan bahan yang akan digunakan disiapkan terlebih dahulu. Biji sorgum disediakan dalam ukuran yang sama (homogen).

Penyiapan Media: Media yang digunakan dalam penelitian ini dibuat 2 unit, yaitu media untuk daya kecambah dan media untuk pertumbuhan sorgum. Media yang digunakan semuanya menggunakan tanah merah, pupuk kandang, dan sekam padi yang dicampur dengan perbandingan 2:1:1 menggunakan polybag ukuran 35 x $35 \mathrm{~cm}$.

Perhitungan Kapasitas Lapang: Menyediakan 3 polybag berisi media yang telah dicampur sebanyak $3 / 4$ bagian. Setelah itu media pada 3 polybag tersebut dioven selama 24 jam sampai konstan dengan suhu $60^{\circ} \mathrm{C}$. Media yang telah di oven, dimasukkan lagi ke dalam 3 polybag semula. Lalu, masing-masing media disiram menggunakan air sebanyak 1,5 liter dan ditunggu selama $24 \mathrm{jam}$. Air yang menetes dalam wadah diukur. Hasil air tetesan yang didapat, lalu dikurangI dengan 1.5 liter air. Hasil ini disebut dengan kapasitas lapang.

Persiapan Benih: Benih yang digunakan yaitu benih yang masak fisiologis yaitu berwarna kecoklatan. Benih direndam dalam mangkuk yang berisi air dan didiamkan selama 24 jam. Biji yang tenggelam diambil dan akan dipakai untuk perlakuan selanjutnya.

Penyiapan Benih untuk Perkecambahan: Benih untuk perkecambahan untuk setiap polybag ditanam 18 biji. Polybag yang dibutuhkan sebanyak 27 polybag ( 9 perlakuan dan 3 ulangan) dilakukan dengan menanam benih sorgum pada masing-masing polybag dengan cara ditugal. Biji yang ditanam atau dibenamkan sesuai dengan tingkat kedalaman sesuai perlakuan. Polybag yang telah ditanami masing-masing 18 biji sorgum tersebut kemudian diletakkan di bawah bangunan pembibitan beratap paranet warna hitam dengan intensitas naungan $60 \%$. Setelah salah satu polybag dapat berkecambah $100 \%$, dengan ciri dengan keluarnya bakal akar atau radikal dari kulit biji maka perkecambahan dihentikan.

\section{Penyiapan Benih untuk Pertumbuhan:} Menyediakan 27 polybag (9 perlakuan dan 3 ulangan). Biji yang sudah disiapkan lalu ditanam dengan kedalaman sesuai perlakuan dengan cara ditugal sebanyak 3 biji/lubang. Setelah itu diletakkan di bawah bangunan pembibitan beratap paranet warna hitam dengan intensitas naungan $60 \%$. Selanjutya dipilih 1 tanaman yang homogen dengan polybag lain. Sisa 2 tanaman yang tumbuh dalam polybag, lalu dicabut.

Perlakuan: Penelitian ini menggunakan 2 faktor perlakuan yaitu volume air dan kedalaman tanam. Perlakuan

perbedaan pemberian volume air, sebagai berikut : $\mathrm{P}_{1}=$ Penyiraman air dengan volume $150 \mathrm{ml}, \mathrm{P}_{2}=$ Penyiraman air dengan volume $300 \mathrm{ml}, \mathrm{P}_{3}=$ Penyiraman air dengan volume $600 \mathrm{ml}$ Perlakuan kedalaman tanam, perlakuan sebagai berikut : $\mathrm{K}_{1}=$ Kedalaman tanam $1 \mathrm{~cm}, \mathrm{~K}_{2}=$ Kedalaman tanam 3 $\mathrm{cm}, \mathrm{K}_{3}=$ Kedalaman tanam $5 \mathrm{~cm}$. Masing-masing perlakuan terdiri atas 1 tanaman yang berada dalam suatu polybag, setiap perlakuan dengan ulangan sebanyak tiga kali.

Pemeliharaan: Melakukan penyiangan ketika tumbuh tanaman liar didalam polybag dengan cara mencabutnya secara rutin.

Parameter Pengamatan: Parameter daya tumbuh benih meliputi persentase perkecambahan, daya kecambah, dan laju perkecambahan. Parameter pertumbuhan yang diamati jumlah daun, tinggi tanaman, berat basah tanaman, bobot kering tanaman, dan panjang akar. 


\section{Persentase Perkecambahan}

Pengamatan persentase perkecambahan dimulai dari hari ketika kecambah muncul tanam sampai masa berhentinya perkecambahan yaitu ketika salah satu polybag berkecambah $100 \%$.

$\mathrm{K}=\frac{\text { Jumlah benih yang berkecambah }}{\text { jumlah benih yang diuji }} \times 100 \%$

\section{Laju Perkecambahan}

Laju perkecambahan dapat diukur dengan cara menghitung dari jumlah hari benih berkecambah, adapun rumusnya sebagai berikut:

Rata - rata hari $=\frac{N 1 T 1+N 2 T 2+\cdots N X T X}{\text { Jumlah benih yang berkecambah }}$
Keterangan: (N) Jumlah benih yang berkecambah setiap hari; (T) Jumlah waktu antara awal pengujian sampai dengan akhir dari interval tertentu suatu pengamatan.

Rancangan Penelitian: Penelitian ini dilaksanakan dengan menggunakan Rancangan Acak Lengkap (RAL) Faktorial dengan 9 perlakuan dan 3 kali ulangan.

\section{HASIL DAN PEMBAHASAN}

Hasil analisis perlakuan perbedaan kedalaman tanam dan volume penyiraman air pada biji sorgum (Sorghum bicolor (L.) Moench.) terhadap persentase perkecambahan dan laju perkecambahan dengan Analysis of Variance (ANOVA) menunjukkan hasil yang tidak berbeda nyata $(\mathrm{P}>0,05)$.

Tabel 1. Rerata persentase perkecambahan (\%) dan laju perkecambahan setelah perlakuan kedalaman tanam dan volume penyiraman air yang berbeda terhadap benih Sorgum (Sorghum bicolor (L.) Moench.)

\begin{tabular}{ccc}
\hline Perlakuan & $\begin{array}{c}\text { Persentase } \\
\text { Perkecambahan }\end{array}$ & Laju Perkecambahan \\
\hline K1P1 (ked 1 cm, 150 ml) & 72,22 & 117,67 \\
K1P2 (ked 1 cm, 300 ml) & 53,70 & 81,00 \\
K1P3 (ked 1 cm, 600 ml) & 59,26 & 98,33 \\
K2P1 (ked 3 cm, 150 ml) & 72,22 & 90,00 \\
K2P2 (ked 3 cm, 300 ml) & 62,96 & 117,33 \\
K2P3 (ked 3 cm, 600 ml) & 79,63 & 129,67 \\
K3P1 (ked 5 cm, 150 ml) & 68,52 & 85,67 \\
K3P2 (ked 5 cm, 300 ml) & 90,74 & 130,00 \\
K3P3 (ked 5 cm, 600 ml) & 83,33 & 124,33 \\
\hline
\end{tabular}

Keterangan: Angka-angka yang diikuti oleh huruf yang sama disatu kolom tidak menunjukkan perbedaan yang nyata berdasarkan uji Duncan pada taraf kepercayaan 95\% (P>0,05).

\section{Persentase Perkecambahan}

Berdasarkan tabel 1, perlakuan K3P2 (kedalaman $5 \mathrm{~cm}$, volume air $300 \mathrm{ml}$ ) memiliki hasil persentase perkecambahan terbaik dengan hasil 90,74\%. Penyebab kecepatan berkecambah diduga karena benih pada saat direndam menyerap air masuk kedalam kulit benih, sehingga menghambat penguapan dan akhirnya dapat menaikkan kandungan kadar air didalam benih dan jika kadar air benih tinggi diatas keseimbangan, maka respirasi pada benih berjalan lebih cepat sehingga meningkatkan energi kecambah pada benih. Hal ini sesuai dengan yang dikemukakan oleh Rukmana dan Yuniarsih (2001) bahwa suatu benih dikatakan mempunyai daya kecambah yang baik apabila persentase perkecambahannya lebih dari $80 \%$. Hal ini diperkuat dengan pendapat Kartasapoetra (2003) yang mengatakan bahwa benih yang berkualitas tinggi itu memiliki viabilitas lebih dari 90\%. Kualitas benih $90 \%$ menjadikan tanaman mampu tumbuh secara normal pada kondisi yang suboptimum dan dapat melanjutkan pertumbuhan secara maksimal. Hasil yang baik ini selain ditunjang oleh faktor lingkungan yang didukung dengan ketersediaan 
cadangan makanan di dalam benih yang juga sangat mendukung dalam proses perkecambahan benih.

Benih yang memiliki viabilitas tinggi mengindikasikan bahwa benih tersebut mempunyai cukup cadangan makanan dalam endosperm yang digunakan sebagai sumber energi oleh benih ketika proses perkecambahan berlangsung. Tujuan perendaman dalam air untuk melunakkan kulit biji sorgum sehingga dapat mempercepat perkecambahan. Menurut Kurnianingsih (2012) perendaman biji dalam air mengakibatkan tumbuh calon akar perkembangan embrio serta perombakan endosperm lebih cepat terjadi, serta untuk memberikan fasilitas masuknya oksigen kedalam biji. Benih yang mempunyai kekuatan tumbuh (vigor) yang baik akan menjadi cepat proses reaktivasi enzimnya apabila kondisi lingkungan tumbuh benih optimum dan proses metabolisme benih tidak terhambat. Benih yang mempunyai vigor baik akan mempunyai nilai kecepatan tumbuh yang tinggi sehingga benih akan cepat berkecambah dalam waktu yang singkat misal pada perlakuan K3P2.

Sebaliknya, benih yang mempunyai vigor buruk akan berpengaruh terhadap fisiologi maupun morfologi tanaman yang dihasilkan. Menurut Sutopo (2002) benih yang memiliki vigor rendah akan berakibat terjadinya kemunduran benih yang cepat selama penyimpanan, makin sempitnya keadaan lingkungan, tempat benih dapat tumbuh, kecepatan berkecambah benih yang menurun, serangan hama dan penyakit meningkat, jumlah kecambah abnormal meningkat, dan rendahnya produksi tanaman

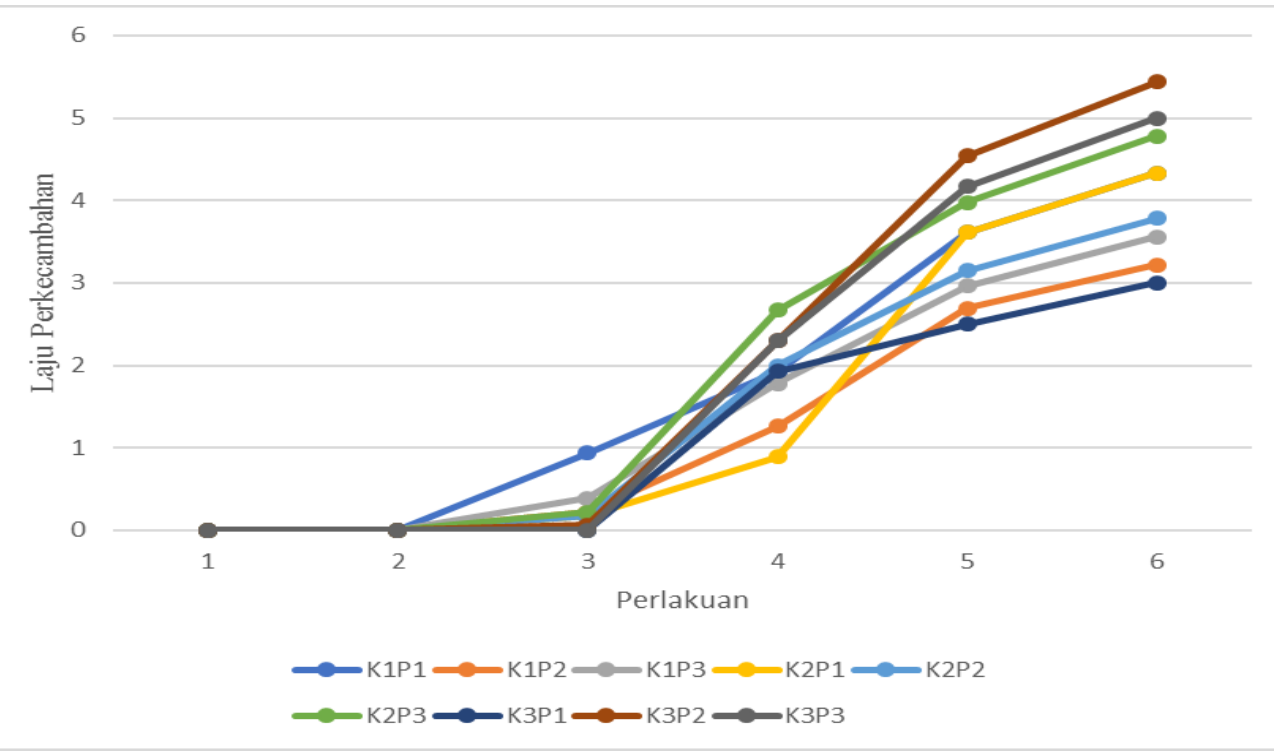

Gambar 1. Kurva sigmoid laju perkecambahan sorgum setelah diberi perlakuan perbedaan kedalaman tanam dan volume air.

\section{Laju Perkecambahan}

Berdasarkan tabel 1, perlakuan K3P2 (kedalaman $5 \mathrm{~cm}$, volume air $300 \mathrm{ml}$ ) memiliki laju perkecambahan terbaik dengan hasil 130,00. Faktor lingkungan merupakan faktor pendukung yang mempengaruhi pertumbuhan dan perkembangan tanaman. Ketika benih ditanam pada kedalaman yang dangkal menyebabkan benih lebih banyak terpapar sinar matahari, sehingga menyebabkan suhu meningkat, akhirnya keserempakan benih saat berkecambah menurun. Ketika benih ditanam lebih dalam menyebabkan benih lebih sedikit menerima cahaya dan suhu tanah menjadi rendah. Kisaran suhu yang dapat ditolerir pada lingkungan pertumbuhan sorgum adalah sekitar $23-30^{\circ} \mathrm{C}$. Pengamatan $\mathrm{pH}$ tanah yang digunakan sebagai media tanam sorgum menunjukkan sifat asam yaitu 5,8 - 5,9. Menurut Putri (2006) pertumbuhan dan perkembangan 
tanaman tidak hanya dipengaruhi oleh ketersediaan unsur hara (makro/mikro) secara cukup, tapi juga faktor lingkungan seperti suhu, $\mathrm{pH}$ dan kelembaban. Suhu optimum untuk tanaman sorgum adalah berkisar antar $20-25^{\circ} \mathrm{C}$. Menurut Purnomohadi (2006) temperatur optimum untuk pertumbuhan tanaman sorgun adala $23-31^{\circ} \mathrm{C}$ dengan kelembaban udara $56-80 \%$. Kondisi tersebut masih termasuk optimal untuk pertumbuhan sorgum.

Kecepatan berkecambah erat hubungannya dengan ciri vigoritas benih. Benih dengan vigoritas tinggi akan mampu tumbuh normal pada kondisi sub optimum dan di atas kondisi normal, memiliki kemampuan tumbuh serempak dan cepat. Menurut Lesilolo, dkk. (2013) kecepatan tumbuh mengindikasikan vigor kekuatan tumbuh benih karena benih yang cepat tumbuh lebih mampu menghadapi kondisi lapang yang sub optimal.

Kurva sigmoid adalah suatu kurva yang mencirikan pola pertumbuhan tanaman (Gardner $e t$ al., 2008). Pola laju perkecambahan sorgum selama percobaan Gambar 4.3. Berdasarkan grafik sigmoid menunjukkan adanya pertumbuhan setiap perlakuan. Pola pertumbuhan sepanjang suatu generasi secara khas dicirikan oleh suatu fungsi pertumbuhan yang disebut kurva sigmoid pertumbuhan cepat pada fase vegetatif sampai titik tertentu akibat pertambahan sel tanaman kemudian melambat dan akhirnya menurun pada fase senesen. Fase logaritmik dapat dilihat dari hari ke1 sampai pada hari ke-2. Kurva menunjukan ukuran kumulatif sebagai fungsi dari waktu. Fase logaritmik berarti bahwa laju pertumbuhan lambat pada awalnya, tapi kemudian meningkat terus. Laju berbanding lurus terhadap ukuran organisme. Fase linier untuk tanaman sorgum dapat dilihat mulai pada hari ke-2 sampai hari ke-5. Hal ini sesuai dengan literatur Salisbury dan Ross (1992) yang menyatakan bahwa fase linier menunjukan pertumbuhan yang berlangsung konstan. Fase penuaan tanaman yang diamati belum terjadi sampai hari ke-6 karena fase penuaan terjadi jika tanaman sudah melewati masa genenatif yaitu pembungaan.

Tabel 2. Rerata laju pertumbuhan tinggi tanaman, jumlah daun, berat basah, berat kering, dan panjang akar tanaman setelah perlakuan kedalaman tanam dan volume air yang bebeda terhadap pertumbuhan tanaman Sorgum (Sorghum bicolor (L.) Moench.)

\begin{tabular}{cccccc}
\hline Perlakuan & $\begin{array}{c}\text { Tinggi } \\
\text { Tanaman } \\
(\mathrm{cm})\end{array}$ & $\begin{array}{c}\text { Jumlah } \\
\text { Daun }\end{array}$ & $\begin{array}{c}\text { Berat } \\
\text { Basah } \\
\text { Tanaman } \\
(\mathrm{gr})\end{array}$ & $\begin{array}{c}\text { Berat } \\
\text { Kering } \\
\text { Tanaman } \\
(\mathrm{gr})\end{array}$ & $\begin{array}{c}\text { Panjang } \\
\text { Akar } \\
\text { Tanaman } \\
(\mathrm{cm})\end{array}$ \\
\hline K1P1 (ked 1 cm, 150 ml) & 84,50 & 4,67 & 21,33 & 5,67 & $46,33^{\mathrm{a}}$ \\
K1P2 (ked 1 cm, 300 ml) & 90,57 & 4,00 & 49,33 & 9,67 & $35,33^{\mathrm{a}}$ \\
K1P3 (ked 1 cm, 600 ml) & 118,67 & 5,00 & 50,67 & 17,67 & $40,00^{\mathrm{a}}$ \\
K2P1 (ked 3 cm, 150 ml) & 104,17 & 5,00 & 19,67 & 7,33 & $47,67^{\mathrm{a}}$ \\
K2P2 (ked 3 cm, 300 ml) & 80,50 & 4,67 & 19,00 & 8,67 & $40,00^{\mathrm{a}}$ \\
K2P3 (ked 3 cm, 600 ml) & 87,17 & 5,00 & 26,67 & 9,00 & $43,67^{\mathrm{a}}$ \\
K3P1 (ked 5 cm, 150 ml) & 97,83 & 4,00 & 23,33 & 6,33 & $72,67^{\mathrm{b}}$ \\
K3P2 (ked 5 cm, 300 ml) & 93,93 & 5,00 & 35,67 & 8,67 & $38,33^{\mathrm{b}}$ \\
K3P3 (ked 5 cm, 600 ml) & 77,87 & 4,37 & 17,33 & 8,00 & $33,67^{\mathrm{b}}$ \\
\hline
\end{tabular}

Keterangan: Angka-angka yang diikuti oleh huruf yang sama disatu kolom tidak menunjukkan perbedaan yang nyata berdasarkan uji Duncan pada taraf kepercayaan $95 \%$.

Hasil analisis perlakuan perbedaan kedalaman tanam dan volume penyiraman air pada biji sorgum varietas Numbu terhadap pertumbuhan tinggi tanaman, jumlah daun dengan Analysis of
Variance (ANOVA) menunjukkan hasil yang tidak berbeda nyata $(\mathrm{P}>0,05)$,sedangkan berat basah tanaman, berat kering tanaman dan panjang akar tanaman menunjukkan hasil berbeda nyata 
$(\mathrm{P}<0,05)$. Berat basah tanaman dan berat kering tanaman sorgum tidak menunjukkan adanya interaksi antara dua faktor $(\mathrm{P}>0,05)$, tetapi panjang akar tanaman sorgum menunjukkan adanya interaksi antara 2 faktor perlakuan perbedaan kedalaman tanam dan volume air $(\mathrm{P}<0,05)$.

\section{Tinggi Tanaman}

Berdasarkan tabel 2, perlakuan K1P3 (kedalaman $1 \mathrm{~cm}$, volume air $600 \mathrm{ml}$ ) memiliki tinggi tanaman terbaik dengan hasil 118,67. Meningkatnya tinggi tanaman adalah hasil perpanjangan ruas-ruas akibat membesarnya selsel dalam jaringan meristem interkalar. Hal ini juga dikarenakan faktor kedalaman tanam yang dangkal menyebabkan benih dapat tumbuh dengan optimal karena dapat menyerap kadar oksigen yang ada dari lapisan permukaan tanah dengan cepat. Selain itu diduga, pemberian air dengan volume $600 \mathrm{ml}$ mampu mencukupi kebutuhan air tanaman sehingga pertumbuhan dan perkembangan tanaman menjadi lebih tinggi. Menurut Rinsema (1983) peningkatan tinggi tanaman merupakan suatu pencerminan dari pertumbuhan tanaman yang menyebabkan perpanjangan ruas-ruas tanaman akibat memanjang dan membesarnya sel-sel dalam jaringan, seiring dengan bertambahnya umur tanaman. Apabila tanaman sorgum kekurangan air, pertumbuhan tinggi tanaman tidak terlalu besar. Mapegau (2006) menyatakan bahwa proses yang sensitif bisa terjadi sebagai dampak dari kekurangan air ialah pembelahan sel. Hal ini dapat diartikan bahwa pertumbuhan tanaman sengat peka terhadap defisit (cekaman) air karena dapat menghentikan pembelahan sel dan mengakibatkan tanaman lebih kecil. Penelitian sebelumnya oleh Minor dalam Mapegau (2006) bahwa pengaruh cekaman kekurangan air pada pertumbuhan tanaman dicerminkan oleh daun-daun yang lebih kecil.

\section{Jumlah Daun}

Berdasarkan tabel 2, perlakuan K1P3 (kedalaman $1 \mathrm{~cm}$, volume air $600 \mathrm{ml}$ ) memiliki jumlah daun terbaik dengan hasil 5,00. Hal ini erat hubungannya dengan tinggi tanaman terbaik dengan banyaknya cahaya yang diserap untuk fotosintesis sehingga menghasilkan jumlah daun yang paling banyak pada kedalaman $1 \mathrm{~cm}$. Hal ini disebabkan pada saat pengamatan jumlah daun sampai minggu keenam dan merupakan fase vegetatif tanaman. Menurut Sumarno, dkk (2013) fase vegetatif bagian tanaman sorgum yang aktif berkembang adalah bagian-bagian vegetatif seperti daun dan tunas. Fase ini sangat penting bagi tanaman karena pada fase ini seluruh daun terbentuk sempurna yang berfungsi memproduksi fotosintat untuk pertumbuhan dan pembentukan biji. Fase vegetatif berlangsung pada saat tanaman berumur antara 1-30 hari. Menurut Firda (2009) selama proses fotosintesis, tanaman yang mampu menghasilkan fotosintat lebih tinggi akan mempunyai banyak daun, karena hasil fotosintat akan digunakan untuk membentuk organ seperti daun dan batang sejalan bertambahnya berat kering tanaman. Semakin banyak cahaya yang diserap tanaman maka fotosintat yang dihasilkan juga semakin tinggi.

\section{Berat Basah}

Berdasarkan tabel 2, perlakuan K1P3 (kedalaman $1 \mathrm{~cm}$, volume air $600 \mathrm{ml}$ ) memiliki berat basah terbaik dengan hasil 50,67. Hal ini menunjukkan perbedaan kedalaman tanam perbedaan berat basah tanaman. Kedalaman tanam berhubungan dengan vigor tanaman. Semakin dalam penanaman maka daya tumbuh tanaman semakin rendah. Semakin rendah daya tumbuhnya menyebabkan pertumbuhan menurun. Hal ini dikarenakan pada saat perkecambahan, kedalaman tanam yang semakin dalam menyebabkan kecepatan berkecambah menjadi rendah yang berarti lebih awal munculnya di permukaan tanah terjadi pada penanaman yang lebih dangkal. Menurut Dzwonko dan Gawronski (2002) kecambah yang lebih dahulu muncul akan memiliki laju tumbuh yang lebih baik sehingga hasil penimbunan biomasa lebih banyak dibandingkan pertumbuhan benih yang muncul lebih lama karena lebih dahulu dapat memanfaatkan lebih banyak cahaya. Hasil penelitian Zheng et al. dan Tobe et al. (2005) 
menunjukkan bahwa semakin dalam penanaman pada suatu media tanam, dapat mempengaruhi jumlah air terserap oleh biji. Menurut Nurdin (2008) peningkatan berat basah dipengaruhi oleh banyaknya absorbsi air dan penimbunan hasil fotosintesis pada daun untuk ditranslokasikan ke seluruh bagian tanaman. Proses fotosintesis yang berlangsung dengan baik, akan memacu penimbunan karbohidrat dan protein pada organ tubuh tanaman. Penimbunan karbohidrat dan protein sebagai akumulasi hasil proses fotosintesis akan berpengaruh pada berat basah tanaman. Air merupakan komponen utama pada tanaman, sekitar $70-90 \%$ berat segar tanaman berupa air yang merupakan media penunjang untuk berlangsungnya reaksi biokimia.

\section{Berat Kering}

Berdasarkan tabel 2, perlakuan K1P3 (kedalaman $1 \mathrm{~cm}$, volume air $600 \mathrm{ml}$ ) memiliki berat kering terbaik dengan hasil 17,67. Semakin dangkal penanaman benih memberikan hasil berat kering tertinggi karena semakin banyak oksigen yang diperoleh bersamaan dengan cahaya matahari yang diserap untuk pertumbuhan mengakibatkan tanaman dapat menimbun biomassa yang lebih banyak.

Menurut Lakitan (2011) hasil berat kering merupakan keseimbangan antara fotosintesis dan respirasi. Fotosintesis mengakibatkan peningkatan berat kering tanaman karena pengambilan $\mathrm{CO}_{2}$, sedangkan respirasi mengakibatkan penurunan berat kering karena pengeluaran $\mathrm{CO}_{2}$. Apabila pertumbuhan relatif tanaman lebih cepat maka hasil fotosintesis lebih baik yang akhirnya berpengaruh pada peningkatan berat kering tanaman. Semakin sedikitnya volume air menyebabkan penurunan berat kering tanaman. Sedikitnya air yang diserap tanaman menyebabkan terhambatnya pertambahan ukuran dan volume selsel pada tanaman, sehingga organ tanaman tidak dapat tumbuh dengan sempurna. Hal ini sesuai dengan pendapat Efendi (1982) bahwa pada tanaman yang kekurangan air akan berpengaruh terhadap penurunan bobot kering.

Akibat dari cekaman dapat juga menyebabkan pertambahan ukuran dan jumlah sel tanaman menjadi terhambat, pertambahan bahan padat atau komponen sel-sel tidak terlalu meningkat, akibatnya berpengaruh terhadap berat kering tanaman misal pada perlakuan K1P3. Tanaman yang mengalami stress air terjadi penurunan laju fotosintesis yang akan berpengaruh terhadap penurunan pertumbuhan, sebaliknya jika terjadi peningkatan fotosintesis maka jumlah fotosintat yang ditranslokasikan ke bagian daun atau tajuk akan menjadi lebih besar.

\section{Panjang Akar}

Berdasarkan tabel 2, perlakuan K3P1 (kedalaman $5 \mathrm{~cm}$, volume air $150 \mathrm{ml}$ ) memiliki panjang akar terbaik dengan hasil 72,67. Hal ini berarti kedalaman tanam $5 \mathrm{~cm}$ merupakan kedalaman yang efektif bagi pertumbuhan akar tanaman sorgum. Semakin rendah penyiraman volume air menyebabkan semakin panjangnya akar tanaman sorgum. Menurut Willat (1986), akar tanaman dapat tumbuh dengan baik jika sebagian pori-pori tanah diameternya lebih besar dari diameter akar atau kekuatan tumbuh akar lebih besar dari kekuatan tanah. Hal ini diperkuat oleh pendapat Nour dan Weibel (1978), jumlah air yang diserap berpengaruh terhadap panjang akar suatu tanaman. Suatu penelitian menunjukkan bahwa kultivar sorgum yang tahan kekeringan, mempunyai perakaran yang lebih panjang dan nisbah akar tajuk yang lebih tinggi dibandingkan kultivar-kultivar yang rentan terhadap kekeringan.

Pemberian air yang terlalu banyak menyebabkan media menjadi jenuh dan berpengaruh buruk pada respirasi akar karena aerasi tanah terganggu. Menurut menurut Hanafiah (2005) pada kondisi jenuh, seluruh ruang pori tanah terisi oleh air yang bergerak relatif cepat, sehingga dapat mencuci unsur-unsur hara yang dilaluinya misal pada perlakuan K1P1 dan K1P2. Jika kondisi ini berlangsung terus-menerus, akan berdampak buruk bagi aerasi tanah.

Tanah dengan kondisi kelebihan air, absorbsi unsur hara menjadi terganggu. Menurut Palupi dan Dedywiryanto (2008) pada umumnya tanaman dengan irigasi yang baik memiliki akar yang lebih panjang dibandingkan dengan tanaman yang tumbuh di tempat yang kering. Walaupun 
demikian, panjang akar berkaitan dengan ketahanan tanaman pada saat terjadi kekurangan air. Hal ini disebabkan karena pada saat kekurangan air, tanaman akan memanjangkan akarnya sampai ke lapisan tanah yang memiliki ketersediaan air yang cukup, sehingga tanaman tersebut dapat bertahan hidup (Djazuli, 2010).

\section{Kesimpulan}

Kedalaman tanam dan volume air berpengaruh terhadap berat basah, berat kering, dan panjang akar tanaman sorgum, tetapi tidak berpengaruh terhadap persentase perkecambahan, laju perkecambahan, tinggi tanaman, dan jumlah daun. Kedalaman tanam dan volume air menunjukkan adanya interaksi terhadap parameter pertumbuhan yaitu panjang akar.Kedalaman tanam dan volume air yang paling optimal untuk persentase perkecambahan, laju perkecambahan, dan pertumbuhan yaitu pada perlakuan K3P2.

\section{DAFTAR PUSTAKA}

Ashari, S. 2006. Hortikultura Aspek Budidaya. UI press. Jakarta. 490 pp.

Dajue and Guangwei. 2000. Sweet sorghum - A fine forage crop for the Beijing region, China. In: Proceedings of the FAO Electronic Conference on Tropical Silage, Roma,Italy

Djazuli, M. 2010. Pengaruh Cekaman Kekeringan Terhadap Pertumbuhan dan Beberapa Karakter Morfo-fisiologis Tanaman Nilam. Bul Littro. 21(1): 8-17

Firda, Y. 2009. Respon tanaman kedelai (Glycine max (L.) Merril) terhadap cekaman kekurangan air dan pemupukan kalium. Skripsi Fakultas Pertanian Universitas Riau : Pekanbaru

Gardner, F. P., Pearce, R. B. and Mitchell, R. L. 1991. Fisiologi Tanaman Budidaya.Universitas Indonesia Press. Jakarta.

Kurnianingsih, N. 2012. Pengaruh Suhu dan Lama Perendaman dalam Air terhadap Perkecambahan Biji Ki Hujan (Samanea saman). Skripsi. Fakultas Sains dan
Teknologi. Universitas Islam Negeri Maulana Malik Ibrahim Malang. Malang.75 h.

Lakitan, B. 2011. Dasar - dasar Fisiologi Tumbuhan. PT. Raja Grafindo Persada : Jakarta. 205 hal

Leisolo, M.K, J. Riry dan E.A. Matatula. 2013. Pengujian Viabilitas dan Vigor Benih Beberapa Jenis Tanaman yang Beredar di Pasaran Kota Ambon. Jurnal Agrologia, 2 (1), 1-9

Mapegau. 2006. Pengaruh Cekaman Air Terhadap Pertumbuhan dan Hasil Tanaman Kedelai. Jurnal Ilmiah Pertanian Kultura.Vol. 41 (1): 43.48

Nurdin, Syahari. 2008. Komoditas Jagung Sebagai Sumber Daya Non Migas. Fakultas Pertanian Universits Hasanudin. Makasar

Nour, A. and D. Weibel. 1978. Evaluation of Root Characteristics in Sorghum Grain. J Agronomy. 70 (5): 217 - 218.

Palupi, E. R., DedywiryantO, Y. 2008. Kajian Karakter Toleransi Cekaman Kekeringan Pada Empat Genotipe Bibit Kelapa Sawit (Elaeis guineensis Jacq). Bul Agron 36 (1): 24-32

Purnomohadi, Mustikoweni. 2006. Potensi Penggunaan Beberapa Varietas Sorgum Sebagai Tanaman Pakan. Ilmu Peternakan Fakultas Kedokteran Hewan : Univesitas Airlangga.

Rukmana R dan Yuniarsih Y. 2001. Usaha Tani Sorghum. Kanisius : Yogyakarta, 8-19

Salisbury, F.B dan C.W. Ross., 1992. Fisiologi Tumbuhan. Jilid Tiga Edisi Keempat. Erlangga : Jakarta Sirappa, M. P. 2003. Prospek Pengembangan Sorgum (Sorghum bicolor (L.) Moench) di Indonesia Sebagai Komoditas Alternatif untuk Pangan, Pakan dan Industri. Jurnal Litbang Pertanian 22(4). BTP Sulawesi Selatan.

Saleh, Salim, M. 2004. Pematahan Dormansi Benih Aren Secara Fisik Pada Berbagai Lama Ekstraksi Buah. Jurnal Agrosains Untad 
Sirappa, M. P. 2003. Prospek Pengembangan Sorgum (Sorghum bicolor (L.) Moench) di Indonesia Sebagai Komoditas Alternatif untuk Pangan, Pakan dan Industri. Jurnal Litbang Pertanian 22(4). BTP Sulawesi Selatan.

Sumarno, Damardjati, D.S., Syam, M., dan Hermanto. 2013. Sorgum : Inovasi Teknologi dan Pengembangan. Jakarta : IAARD Press.

Sutopo, L. 2002. Teknologi Benih. CV. Rajawali : Jakarta. 237pp.

Willat. 1988. The Grawth of Maize after Wetland Rice in East Java. Proc, 11 th, Conf.Int. Soil Tillage Re.Org.,Edinburg 2: 